\title{
IdeAs
}

Idées d'Amériques

\section{¿Revolucionarios o peronistas? Los años 1960-1970 en Argentina bajo el prisma de la categoría de populismo}

Révolutionnaires ou péronistes? Les années 1960-1970 en Argentine sous le prisme du populisme

Revolutionaries or peronists? The years 1960-1970 in Argentina under the prism of the category of populism ¿Revolucionarios o peronistas? Los años 1960-1970 en Argentina bajo el prisma de la categoría de populismo

\section{Humberto Cucchetti}

\section{OpenEdition}

\section{Journals}

Edición electrónica

URL: http://journals.openedition.org/ideas/6205

DOI: 10.4000/ideas.6205

ISSN: $1950-5701$

\section{Editor}

Institut des Amériques

Referencia electrónica

Humberto Cucchetti, « ¿Revolucionarios o peronistas? Los años 1960-1970 en Argentina bajo el prisma de la categoría de populismo », IdeAs [En línea], 14 | 2019, Puesto en línea el 01 octubre 2019, consultado el 08 noviembre 2019. URL : http://journals.openedition.org/ideas/6205 ; DOI : 10.4000/ ideas.6205

Este documento fue generado automáticamente el 8 noviembre 2019

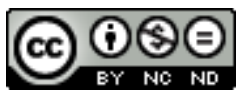

IdeAs - Idées d'Amériques est mis à disposition selon les termes de la licence Creative Commons Attribution - Pas d'Utilisation Commerciale - Pas de Modification 4.0 International. 


\section{¿Revolucionarios o peronistas? Los años 1960-1970 en Argentina bajo el prisma de la categoría de populismo}

Révolutionnaires ou péronistes? Les années 1960-1970 en Argentine sous le prisme du populisme

Revolutionaries or peronists? The years 1960-1970 in Argentina under the prism of the category of populism

¿Revolucionarios o peronistas? Los años 1960-1970 en Argentina bajo el prisma de la categoría de populismo

\section{Humberto Cucchetti}

\section{Introducción}

1 El peronismo o justicialismo ${ }^{1}$ habría encarnado, en su primer gran período de existencia (1944-1955), una manifestación típico-ideal de la categoría de populismo. Es cierto, tal caracterización no es excluyente de otras más o menos contiguas, como lo son los debates sobre los totalitarismos y, en especial, los fascismos. Su abordaje en términos de régimen autoritario "nacional-popular" alcanzó, desde la evolución de los trabajos del sociólogo italiano radicado en Argentina Gino Germani (Amaral S., 2018), un cierto consenso en la descripción de las dinámicas sociopolíticas presentes en tal fenómeno. Desde dicha veta, otras lecturas más recientes coinciden en definirlo como “nacional-populismo" (Taguieff P-A, 2002) o, alternativa y recientemente, en términos de “democracia hegemónica” (Rouquié A., 2016).

El peronismo histórico, o primer peronismo, se estructura alrededor de un Estado redistribuidor, de sectores industriales y sindicales, alrededor de principios nacionalistas y tomando como eje dos figuras: Juan Domingo Perón (1895-1974)² y Eva Duarte de Perón (1919- 1952) ${ }^{3}$. ¿Qué sucede, en cambio, cuando pretende abordarse una etapa de la historia peronista en la que sus parámetros de funcionamiento y 
reproducción parecen profundamente amenazados? Tal es el caso del período largo, complejo e internamente contradictorio que se abre desde el golpe de Estado de 1955 hasta el fallecimiento de Juan Perón, en plena tercera presidencia, el 1 de julio de 1974. Se ha señalado que la plasticidad organizativa es un rasgo central para comprender la larga historia de la supervivencia peronista (Levitsky S., 2005). Sin embargo, en el cruce de dos niveles históricos, el de la historia local y el de las circulaciones transnacionales, el período 1955- 1974 ofrece un contexto singular del cual los actores peronistas no están exentos. Entre la radicalización de una experiencia social y política que ha sido desalojada militarmente del poder (con el propio Perón destinado a un largo y por momentos penoso exilio), y la emergencia de una radicalización juvenil y universitaria por demás dinámica a escala internacional, un significado singular de lo revolucionario penetra los espacios militantes y actividades de la adhesión peronista.

A partir de esta base histórica, retomando debates historiográficos así como elementos empíricos diversos, podemos abordar el interrogante que se presenta en el título de nuestra contribución. En ese sentido, evocar la pertinencia de la idea de populismo para dar cuenta de las transformaciones atravesadas por el movimiento en cuestión durante la época aludida busca enriquecer la comprensión de las tensiones que se presentan en los años de la radicalización justicialista. Para ello, hemos organizado nuestra contribución en tres grandes momentos. En primer lugar, ofreceremos una síntesis bibliográfica donde se aborda de diferentes ángulos, a veces indirectamente, el problema de nuestro análisis. En segundo lugar, apelando a fuentes heterogéneas y a investigaciones precisas y minuciosas, abordaremos cómo se presenta una relación de solidaridad/tensión entre las manifestaciones más clásicas del fenómeno (que podrían ser calificadas de "populistas") y expresiones de una radicalidad que se propone ir más allá de los marcos conocidos, hasta la época, de la acción peronista. Finalmente, como conclusión, damos cuenta de un debate no saldado alrededor de tal cuestión, pensando en qué medida la exacerbación de principios revolucionarios habría evacuado (o no) los elementos constitutivos de la adhesión peronista. En particular uno de ellos, la fidelidad a Perón. La aclimatación de procesos transnacionales (guerras anticolonialistas, Revolución cubana y Concilio Vaticano II), ofrece así otros temas de discusión que aluden a la capacidad de absorción (y a los límites de la misma) que evidenció el peronismo en tales años.

\section{Las dinámicas contestatarias en los sesenta : un aporte bibliográfico}

4 Una primera y sintética lectura del período abordado 4 nos lleva a constatar que el eje conceptual "populismo" se ve en gran medida desplazado por otros fenómenos preponderantes (agitación revolucionaria, organizaciones armadas, Nueva Izquierda, compromiso juvenil, radicalización política, etc.). Sin embargo, este desplazamiento no es total ya que algunas alusiones a la cuestión populista emergen más no sea indirectamente en determinadas interpretaciones.

5 Es importante no olvidar que los cambios sociales y culturales (Manzano V., 2017; Cosse I., 2010) que vive el país no son ajenos procesos más vastos que se presentan en diferentes sociedades nacionales (Hobsbawm E., 1994). Ahora bien, la extensión de la población universitaria, así como la influencia de revueltas estudiantiles en Argentina, están ambas asociadas a particularidades propias de la política local que refractan en 
gran medida los rasgos propios de la politización juvenil - que en el país se conoció como "nacionalización" y/o "peronización" de los estudiantes 5 . El peronismo, resignificado en clave disruptiva debido a su exilio y a la permanencia de la fidelidad que aún despertaba en los medios obreros, comenzaba a expresar un valor contestatario, una revisión revolucionaria de tipo "maoísta" (léase "popular") del principio de la guerra prolongada de masas. Esto es, la etapa clásica de la guerra fría (bloque capitalista vs. bloque comunista) daba lugar a conflictos dispersos y triangulares, donde los intereses del Tercer mundo podían pensarse localmente, aunque sin ahorrar conflictos y controversias, a partir de la adhesión al peronismo entendido como socialismo nacional.

6 Así, tales años en ebullición son marcados por dimensiones bien arraigadas en la política argentina, a saber su fuerte inestabilidad institucional y la "legitimidad perdida" en su sistema político: la erradicación del peronismo de la vida política, las proscripciones parciales o totales de éste último, así como el grado de politización de las Fuerzas Armadas son incentivos importantes que favorecen la extensión y radicalización de la actividad contestataria extra-partidaria. Todo esto, potenciado por acontecimientos internacionales que se inscriben en una cultura general proclive a la transformación estructural del orden vigente.

7 La proscripción del peronismo, la emergencia de la llamada Resistencia ${ }^{7}$, la existencia de un sindicalismo combativo y la persistencia de una identidad popular peronista llevaron a reconocer su radicalidad y su "potencialidad" revolucionaria. Como en pocos escenarios, la Argentina de los sesenta mostró la coexistencia, la cooperación (también los antagonismos) entre aquello que Pascal Ory (2017) advirtió, para diferentes sociedades y momentos históricos, como dos fenómenos unidos por un tronco mesiánico y utópico común : mitología de izquierda radical y reivindicación populista.

8 La reconsideración del peronismo entrañó un fenómeno vasto, de adhesión a un movimiento aborrecido en 1955, que había sido calificado sucesivamente de nazifascismo, totalitarismo, autoritarismo o, buscando una fórmula más matizada, “movimiento nacional popular" (Amaral S., 2018). Diferentes oleadas autoritarias tanto civiles como militares, y con la ayuda de una revalorización de la idea de pueblo y de los métodos insurreccionales, generaron la llegada de nuevos actores al peronismo. Desde este punto vista, se trata de un dinámica de clase social, de la llamada "clase media" que, sobre todo a partir de sus trayectorias intelectuales, habría extrapolado sus orientaciones de clase social (sentimiento de vanguardia, objetivos socialistas) hacia peronismo (Spinelli M-E., 2013). Tal idealización (Sigal S., 1991) no habría impedido la reproducción de viejos prejuicios antiperonistas (desconfianza hacia Perón, rechazo hacia la dirigencia sindical) en el interior del propio movimiento justicialista (Spinelli M-E., 2013:203).

9 Conviene destacar que una parte importante de los estudios propuestos giraron alrededor de indagaciones típicas en términos de historia intelectual. La revalorización del peronismo, incluso su definición, es obra de intelectuales comprometidos en los debates públicos (Neiburg F., 1998). Progresivamente, se fue construyendo un campo "nacional-revolucionario" en el cual los intelectuales de izquierda comenzaron a comprender el peronismo bajo otras connotaciones, imponiendo una apertura hacia la cuestión nacional (Georgieff G., 2008). El peronismo fue un re-ordenador de las significaciones de la cultura de izquierda, promoviendo un encuentro entre socialismo y nación (Altamirano C., 2011:97). Así, esta revisión supuso un fenómeno de clase - 
actores provenientes de los sectores medios y universitarios que se ocupaban de desterrar la vieja asociación fascismo-peronismo para proponer a este último como horizonte de la transformación social. Esto supuso igualmente una verdadera representación de la clase media como actor de la historia argentina a partir de una lectura populista : el encuentro con el peronismo, según Oscar Terán, ofrecía una "estructura de culpabilización" donde se denunciaba su "europeísmo", sus opciones desacertadas durante el 17 de Octubre de 1945 (Terán O., 2017:93-94, 139). En contrapartida, la idea de un "pueblo sano" integraba esta retórica (Terán O., 2017:167-168). Se van cimentando así las bases de un populismo radical que movilizará, tiempo después, referencias intelectuales y activistas, dando lugar a la memoria de un "peronismo verdadero" que se encarnará en Montonero: allí, la revolución se transformará en un hecho absoluto (Altamirano C., 2011:154- 157).

Además de la dimensión intelectual señalada más arriba, una idea emerge para dar cuenta de la especificidad de tal proceso de ebullición política y cultural: la Nueva Izquierda. Se trata de un efecto de generación y de ruptura generacional producido por el hecho peronista (Altamirano C., 2011:70-73). Se trata, asimismo, de un fenómeno activista, que en su versión extrema incluyó la radicalización armada. La expresión conoce una gran diversidad de significados según los autores y las autoras en cuestión (Tortti M-C., 2000), abarcando fenómenos y manifestaciones heterogéneos, incluso contradictorios. Además de sus ribetes intelectuales, la Nueva Izquierda habría incluido todo un entramado de emergencia generacional y de crítica interna en el seno de la izquierda argentina que, desde mediados de los años 1950, comienza a poner en tela de juicio a sus partidos tradicionales (el Partido Comunista y el Partido Socialista). Una forma de delimitar el fenómeno consiste en atribuirle, a tal manifestación, la creación, hacia fines de los años 1960 e inicios de la década de 1970, de organizaciones de lucha armada (Hilb C.- Lutzky D., 1984). Sin embargo, las manifestaciones históricamente anteriores de tal emergente generacional incluyeron actores colectivos e itinerarios individuales que no desembocaron en la lucha armada, o que su acceso al horizonte guerrillero fue por demás complejo 8 .

11 De este modo, conviene abordar el fenómeno justamente a partir de su complejidad : la violencia política cristalizada finalmente en organizaciones férreamente militarizadas, y las memorias anacrónicamente inteligibles que emanarán del heroísmo revolucionario, serán la tentativa de simplificación extrema de un proceso que, desde la caída de Perón en 1955, fue por demás imprevisible y nebuloso. Desde un punto de vista cultural, la revisión del peronismo supuso una transformación de sus representaciones visuales. Desde el punto de vista de la imagen, así como en función de sus características sociales y conceptuales, se produjo una "remarcable transformación" del peronismo, yuxtaponiéndose imaginario popular e imaginario de la revuelta (Cristiá M., 2016:221), que retomaba tramas culturales diversas en el seno de un “imaginario revolucionario transnacional". Emergió así el mito revolucionario de Eva Perón (explotado en los años 1970, como el de Evita Montonera), que expresa la irrupción de valores culturales modernos y la re-significación del rol disruptivo moral y político que encarnaba la segunda esposa del General (Ehrlich L., 2018). En pleno tercer gobierno de Perón, Eva será el centro de disputas simbólicas y estéticas: mártir popular, ella podía ser recuperada en clave revolucionaria por unos, o de manera maternal por el gobierno justicialista y sus versiones más tradicionales (Cristiá M., 227:2016). 
12 El debate sobre el significado final de la guerrilla peronista sigue por lo tanto abierto. $¿^{\text {Representó Montoneros }}{ }^{9}$ la tentativa de una guerrilla nacionalista - viendo el origen católico y nacionalista de una parte de sus fundadores, la presencia de redes católiconacionalistas en su interior, y el respeto programático de principios de intervención estatal en el marco de una economía de mercado? ¿Fue una tentativa estrictamente socialista que buscaba la colectivización de las áreas económicas argentinas? ¿O ese socialismo se definía básicamente por su voluntad de satelización explícita y concreta dentro de la influencia diplomática cubana - lo que habría podido generar, de manera casi paradójica, el único caso de imitación exitosa del “dos, tres, muchos Vietnam”, una insurrección guevarista a la argentina, en medio de una sociedad urbana y fuertemente industrial?

13 Las respuestas pueden ser legítimamente diversas ya que el proyecto en cuestión fracasó, que su resultado final no puede ser apreciado globalmente y que las interpretaciones dependen de algunas de sus manifestaciones empíricas parciales. El desarrollo de la Tendencia revolucionaria del peronismo significa, para algunos autores, la presencia de una heterogeneidad radical entre el peronismo de Perón, la organización carismática construida a partir de una identidad populista, y el universo del peronismo revolucionario. Para Samuel Amaral, en una célebre obra colectiva, los "católicos Montoneros descendían del entrismo trotskista practicado tras la caída de Perón" : "reclamarse peronistas" les habría permitido tener una penetración política de relativa importancia evitando su reducción a simple "maquinaria militar" (Amaral S., 1993:304). En la misma línea, otros autores señalaron que varios documentos programáticos de tal organización ("Plenario" de 1968, "Estrategia y tácticas revolucionarias" del mismo año, y "Ateneo" de 1969) buscaban nítidamente "la instalación en Argentina de un sistema socialista" (Salcedo J., 2015:251). Desde el punto de vista de la sociología política, y analizando las modalidades de organización de las clases populares a partir de tipologías extraídas de manifestaciones latinoamericanas, el sociólogo Torcuato Di Tella propone básicamente dos (además de los partidos socialistas obreros y de los partidos populistas de clase media), que reflejan, justamente por su definición típico-ideal, una delimitación neta entre pertenencia populista y pertenencia revolucionaria (Di Tella T., 2011:239-241): los partidos socialrevolucionarios ("fidelistas") y los partidos obreros populistas ("peronistas o chavistas").

Al contrario, en otra línea de interpretación (Lanusse L., 2010:266-267) se señala que, en la pluralidad de concepciones existentes dentro de la guerrilla peronista, habría coexistido un conjunto de tensiones constitutivas en lo referente a la relación con el peronismo: la expresión "movimientista" (quienes creían que el peronismo era revolucionario y relegaban sus diferencias con él), la "tendencia revolucionaria" (quienes ponían el acento en su potencialidad revolucionaria, conviviendo así tácticamente con los "burócratas"), finalmente los "alternativistas" (quienes mantenían la identidad peronista sin querer convivir con los burócratas, y definiendo al líder como referente "burgués"). Sin embargo, en esta misma línea se reconoce que uno de los grupos originales de Montoneros, el erigido alrededor de Emilio Maza y Fernando Abal Medina, encarnaba, previo a su fundación, su expresión más foquista (Lanusse L., 2006:132, 141-142). Hacia 1972, Montoneros se habría estructurado en función del foquismo "teorizado" por Régis Debray pero de una forma híbrida: aceptaba el rol político de Perón (aspecto impensable en el imaginario guevarista, y en 
el del intelectual francés), aunque de manera secundaria (en el origen de profundas tensiones con el resto del mundo peronista). Populismo y revolución: ¿tensión, enemistad, afinidad o síntesis?

\section{Revolución y pueblo: ¿un populismo a la escala militante?}

Podemos abordar las consideraciones bibliográficas precedentes a la luz de manifestaciones sociopolíticas dispersas. En efecto, el mundo rasante de los militantes, de sus proyectos, de sus redes, de sus organizaciones y de sus itinerarios nos lleva a precisar finamente el alcance de algunos procesos de politización. Ello completa, a veces, o corrige, en otras oportunidades, algunas consideraciones meramente intelectuales o generalizantes.

La profundización contestataria durante la segunda mitad de la década de 1960, y los tejidos de la Tendencia Revolucionaria en los primeros años de la década siguiente, se proponen revalorizar a la Resistencia Peronista como primer modelo insurreccional de intransigencia peronista. En efecto, la lógica de la violencia se fue gestando en respuesta a las decisiones más drásticamente antiperonistas que se toman desde fines de 1955. Sin embargo, los actores concretos, las prácticas utilizadas y las representaciones construidas obedecieron a entramados mucho más complejos que los argumentos invocados por Montoneros alrededor de la "Patria Socialista".

17 La exclusión de Perón de la vida política argentina fue total, la del peronismo por momentos también lo fue. La represión de sus adherentes, extremadamente dura. Y la desactivación de ciertas tentativas de recuperación del poder, netamente sangrienta. En junio de 1956, militares peronistas producen un levantamiento que es finalmente aplastado y sus responsables fusilados. La memoria entroniza tal gesta, la visualiza como un episodio tendiente a producir el retorno de Perón al país. En los hechos históricos, la afinidad entre tales militares y el líder exiliado, y la aceptación de este último a tal modalidad de recuperación del poder (lo que, en los hechos, debilitaba su autoridad popular máxima) es mucho menos evidente (Melón Pirro J., 2009). Ese peronismo insurreccional, aun cuando se manifestaba extremadamente devoto de la figura de Perón, producía imágenes difícilmente compatibles con el estilo y la trayectoria de este último. Incluso, podía desafiar veladamente sus decisiones, apelando a diferentes declaraciones falsificadas, desautorizando por ejemplo el acuerdo entre el líder y el dirigente radical Arturo Frondizi para las elecciones presidenciales de $1958^{10}$.

Así, la Resistencia, tiempo después mitificada, encarnó en los hechos un "terrorismo amateur" (Melón Pirro J., 2009: 245). Y tuvo manifestaciones en diferentes puntos urbanos del país (Álvarez Y., 2016). Lo guerrillero se erigió, y antes del éxito de la Revolución cubana, en un valor de la cultura peronista ${ }^{11}$ - al menos para sus activistas y para los nuevos compagnons de route. En la primera mitad de los años 1960, varias publicaciones militantes y organizaciones de juventud, que por momentos fueron estrictamente grupúsculos, desarrollaron una actividad política y de propaganda intensas ${ }^{12}$. En ese contexto, ven la luz organizaciones como Guardia de Hierro ${ }^{13}$, el Comando de Organización, el Movimiento Nacionalista Revolucionario Tacuara, el Movimiento Revolucionario Peronista, entre otros núcleos de juventud peronista. Y publicaciones diversas, vinculadas a diferentes espacios de activistas : Trinchera de la 
Juventud Peronista, Palabra Argentina, GH, Argentinos a la lucha, 18 de Marzo, entre otras. Como ha sido señalado (Ehrlich L., 2013), antes de la realización del Concilio Vaticano II y de la impronta guevarista alrededor del "Hombre Nuevo" comenzó a manifestarse un "combativismo juvenil" alrededor de figuras heroicas y sacrificiales provenientes de referencias católicas y del nacionalismo. Ello podría incluso invertir los argumentos explicativos, ya que podría pensarse en el rol jugado por trayectorias nacionalistas en el proyecto de Guevara - por ejemplo, el caso del ex miembro de la Alianza Libertadora Nacionalista argentina, Jorge Masetti (Rot G., 2010) -, lo que habría contribuido a gestar la ética revolucionaria del sacrificio. Los actores, los espacios de sociabilidad y los valores activistas que animaron el clima contestatario a principios de los años 1960 encontraron en el peronismo el vehículo ideal en términos de pertenencia insurreccional. Los orígenes católicos de tales vectores de la contestación y las reivindicaciones políticas nacionalistas nutrieron en gran medida dicha pertenencia.

19 Así, las representaciones revolucionarias estuvieron bien extendidas en el arco de los órganos de propaganda peronista. La militancia territorial, sindical y activista implicaba la existencia de publicaciones militantes dirigidas por los jóvenes militantes que se entrenaron políticamente en las experiencias y los valores de la Resistencia. Para citar un solo ejemplo, es el caso de la publicación Compañeros, fundada en 1963, núcleo a partir del cual se constituye el Movimiento Revolucionario Peronista (MRP). En esas páginas, se repetían algunos valores clásicos de un peronismo entendido en clave insurreccional. Perón era un dirigente revolucionario, Eva, una líder revolucionaria ; gran parte de la dirigencia sindical y partidaria eran burócratas que traicionaban el más genuino legado de Perón; el discurso implicaba la adopción de una violencia retórica incontestable, y una idealización del sacrificio activista (Funes A., 2018).

El lenguaje contestatario, las apelaciones guerreras y la denunciación del capitalismo y del imperialismo, elementos que podrían significar una profunda atracción en términos de utopía radical de izquierda, no se invocaba al interior de las izquierdas, del esquema analítico del marxismo o de los objetivos del colectivismo socialista. La izquierda argentina, para muchos de estos actores, integraba el amplio mundo antiperonista, y una enajenación con respecto a los intereses nacionales y populares. La aceptación de la Revolución cubana era posible en tanto que modalidad nacional de la liberación nacional - el peronismo era el representante exclusivo de esta misma pretensión en Argentina (Funes A., 2018:130, 167). La posibilidad, sin embargo, de desembocar en una concepción "leninista" (foquista) de la guerra revolucionaria no estaba completamente descartada.

21 Sin embargo, la radicalización ideológica no produjo necesariamente una radicalización política en términos de violencia guerrillera (Ollier M., 1998). Desde el nacionalismo y desde el peronismo intransigente, munidos de una retórica insurreccional, no se llegó necesariamente a la violencia armada - en algunos casos, hubo, entre 1973 y 1976, una oposición visceral al foquismo. Comprender tales bifurcaciones (de la agitación sesentista a la oposición a la lucha armada) y pasajes (del peronismo a la guerrilla guevarista, de los orígenes de izquierda al peronismo revolucionario) es central para dar cuenta de la complejidad existente en los itinerarios militantes de la época.

La fascinación resistente que había producido la radicalidad peronista en un contexto de exclusión política trastocó la antigua identificación que diferentes voceros tradicionales de la izquierda argentina habían producido del justicialismo como versión local del fascismo. No se trató sólo (ni tanto) de un fenómeno intelectual sino de un 
conjunto de experiencias concretas en términos de sociabilidad y de mutación de pertenencias.

Así, en tanto que representación nativa, el populismo como identidad no constituye un dato siempre evidente ${ }^{14}$. En algunos casos, como en ciertas variantes clasistas (peronistas o no), se rechaza explícitamente la identidad populista - entre otras manifestaciones que eran ajenas a la clase obrera. En otros casos, al contrario, la retórica que insiste en una identidad popular inextricablemente ligada al peronismo resulta un vector esencial dentro de la justificación de la adhesión política. Hemos encontrado tal vector en entrevistas realizadas a militantes politizados durante los años 1960, provenientes de diferentes ciudades argentinas ${ }^{15}$. Sus orígenes socioeconómicos son diversos, la mayoría habiendo realizado estudios universitarios. Ideológicamente, los peronistas puros (es decir, aquellos que surgieron de familias peronistas y que no habrían tenidos mayores dilemas al momento de participar políticamente en las filas de tal movimiento político) son raros. En ellos, incluso, adherir al peronismo supuso alguna forma de reinvención de la pertenencia (su peronismo no es el mismo que el de sus familias de origen) o de rodeo por organizaciones nacionalistas o de izquierda - en este sentido, la familia no socializa políticamente de manera automática o transparente. Para los ajenos al "movimiento nacional", los antecedentes previos al "encuentro" con el pueblo podían provenir de la izquierda trotskista, del socialismo, de las juventudes comunistas, de los activistas formados en Tacuara, de otros espacios nacionalistas, del compromiso católico y de la democracia cristiana (este último no coincide siempre con la participación en las filas del movimiento católico), entre otras opciones posibles.

24 Podemos citar una trayectoria individual cuya socialización política proviene de espacios bien alejados del movimiento peronista, cuando no hostiles a este último. Roberto Grabois, procedente de una "clase media judía" (Grabois R., 2014:21), quien tiene 12 años en las jornadas que desembocan en el derrocamiento de Perón en 1955, proviene del Partido Socialista (PS). Su familia tenía una relación extremadamente estrecha con el dirigente socialista David Tieffemberg. Allí comenzó siendo un precoz militante de la rama juvenil. En la segunda mitad de los años 1950, y producto de la penetración que el hecho peronista producía en el partido (caracterizado hasta allí por su marcado socialismo liberal y, consecuentemente, su antiperonismo), el PS atravesó escisiones y disidencias. Grabois fue testigo de ellas. Diferentes cuadros socialistas comenzaron a entablar relaciones con miembros de la Resistencia peronista. La Revolución cubana y la invasión de Bahía de los Cochinos en 1961 produjeron nuevas tensiones en este espacio partidario.

En su propia experiencia, él atraviesa una serie de decepciones. En 1961, precisamente, asiste, como miembro de la delegación socialista, al Foro de las Juventudes en la Unión Soviética. Según su relato, allí descubre una realidad que está muy alejada de la idea de progreso social y de humanismo con el que se identificaba al comunismo (Grabois R., 2014:80-98). Al mismo tiempo, sus redes militantes en Argentina comenzaban a alistarse detrás del proyecto de Guevara. Ello lo llevó a confirmar la existencia de solidaridades por demás ceñidas entre "aparato cubano", estrategia continental y cuadros socialistas (Grabois R., 2014:75). Como dirigente estudiantil, y profundizando sus contactos con redes del peronismo revolucionario de la época (por ejemplo, el dirigente de la Juventud Peronista Gustavo Rearte), Grabois comenzó a construir una legitimidad en el interior de las agrupaciones universitarias. Progresivamente, y debido 
a la presencia del "aparato cubano" (verdadera constante en su relato), él manifestó una creciente identificación con el peronismo. Cheville ouvrière del Frente Estudiantil Nacional (FEN), proceso organizativo que data de mediados de los años 1960, con implantación en los principales centros universitarios del país, Grabois propone una justificación intelectual que insiste con dos tiempos de adhesión política, la "nacionalización" y, enseguida, la "peronización" de los estudiantes. En 1971, en representación del FEN, se reúne con Perón para sellar el ingreso de su agrupación a las huestes peronistas.

Entrevistado junto a otros dirigentes estudiantiles por los realizadores Fernando Solanas y Osvaldo Gettino en el marco del célebre documental La hora de los hornos (1968), Grabois precisa el deber de las luchas universitarias, subordinadas a las luchas nacionales, lo que da pie a comprender cuál es el valor específico (es decir, no en tanto que "modelo a imitar"), de la Revolución cubana.

“... tal vez lo que podríamos decir, que lo que caracteriza el proceso del movimiento estudiantil, venir desde el universitarismo, entendido éste como el de la lucha de grandes ideales desde una perspectiva estrecha, parcializada como universitarios, y de tipo paternalista respecto al movimiento popular, hacia una conciencia nacional entendida ésta como fusión con el movimiento popular. Conciencia de que la lucha por una patria liberada, por una patria socialista, deviene inevitablemente de nuestra fusión con el eje fundamental de la revolución argentina, que es la clase obrera. Y una clase obrera no entendida como categoría abstracta, sino entendida en su historia, en sus luchas, en sus sentimientos. Y de allí lo fundamental también, el proceso de toma de conciencia nacional, es la comprensión, la valorización como cosa nuestra, como cosa propia, del proceso peronista, del significado del peronismo para la clase obrera argentina. El peronismo no de los burócratas, entregadores de la lucha para la negociación y la conciliación. El peronismo de las masas, el peronismo de la lucha antiimperialista, el peronismo anti-yanqui, revolucionario, que marca, sin dudas, el derrotero del camino nacional hacia el socialismo. En este sentido, ha tenido una gran influencia el proceso de la Revolución cubana. Revolución nacional, nacionalista y antiimperialista que, en cuyo legado, es para nosotros, marxistas-leninistas, no interpretar este método y esta guía para la acción como un sombrero para pretender encasillar e impostarlo al movimiento popular. Sino como un método de encuentro, de entronque, con la Historia, con la vida de nuestra clase obrera, para gestar en conjunto, con ella adelante, junto a nuestro pueblo, en el camino de la liberación nacional y hacia la construcción del socialismo"16.

Tal visión busca situar el rol positivo de la experiencia cubana ${ }^{17}$, sin sostenerla como eje o modelo de la transformación política en Argentina, y sin dar lugar tampoco a un posicionamiento anticastrista. Es decir, Grabois hace explícita su procedencia "marxista-leninista", el hecho de no haber nacido en el peronismo. Es más, esto incluye una crítica al "universitarismo", en el cual la reivindicación particular realizada desde los "grandes ideales" es efectúa desde una "perspectiva estrecha". Se trata de evocar la vieja antinomia entre intelectuales y peronismo, entre universidad y pueblo. La "toma de conciencia" implica un reconocimiento de lo nacional, de la identidad obrera (peronista), de la particularidad de la revolución argentina. Allí se inscribe el camino nacional hacia el socialismo, la vía revolucionaria que, en clave anti-imperialista, debía hacer posible a la liberación nacional. ¿Revolución cubana? Sí, pero en Cuba. Lo cual muestra la complejidad que manifestarán las oposiciones y alianzas políticas durante los años 1970 cuando, el propio presidente Perón se encargue de invocar, ante la continuidad operativa de las organizaciones armadas, el deber de erradicar toda forma de guerrilla. 
28 Ahora bien, dicha centralidad alrededor de la figura de Perón no excluía otras pertenencias que se fueron elaborando, las que resuelven la ecuación "pueblo- clase obrera - identidad política" de otra manera. El "peronismo de base" expresa, a inicios de los años 1970, una reivindicación atravesada de críticas hacia los "enemigos internos". El proyecto, una organización independiente de la clase obrera - que llegaba casi a la incompatibilidad con el movimiento que reivindicaban. Alrededor de una cultura clasista, podía afirmarse que "ya no creemos en "desarrollistas", "nacionalistas", "populistas", "golpistas", solo creemos en nuestras propias fuerzas de clase explotada"18, agregando además que "nosotros no somos "populistas revolucionarios" porque creemos que la clase obrera es la que tiene la capacidad numérica y de decisión para dirigir un proceso revolucionario y para construir una sociedad sin explotación"19. Entonces, tal peronismo de corte clasista pretendía purificar las deformaciones, las "nostalgias" y las "traiciones" en el seno del propio movimiento político buscando concretar la utopía de una organización plenamente autónoma de la clase obrera.

\section{Reflexiones finales: solidaridad y tensión entre pertenencias disruptivas}

29 La presente contribución aborda en gran medida una relación que el historiador y ensayista Carlos Altamirano describió en términos de "peronismo y cultura de izquierdas" (Altamirano C., 2011). Los términos deben, sin embargo, ser formulados en plural para captar la complejidad de interacciones extremadamente dinámicas, donde la cristalización de los programas, doctrinas e ideologías se diluye en el carácter difuso, histórico y maleable de las pertenencias políticas. Hubo, entonces, peronismos e izquierdas, deudores del mismo contexto, y con respuestas a veces similares y continuas, a veces opuestas.

En términos conceptuales, ¿cuál es la pertinencia de la idea de populismo en un período signado por la puesta en suspenso de la dominación carismática, por el avance de la identidad revolucionaria y de la cultura disruptiva, por el auge de proyectos socialistas definidos igualmente en ruptura con la tutela comunista tributaria de la coexistencia pacífica y de la supremacía diplomática soviética? La pregunta incluye interrogantes diversos, pero queda claro que, como hemos abordado en otros trabajos (Cucchetti H., 2013), el guerrillerismo justicialista que emerge en el contexto de la Resistencia se realimenta de la emergencia del fenómeno cubano y de otras legitimidades tercermundistas. La dominación carismática, en cuestionamiento por el exilio del fundador, se potencia con una reapropiación revolucionaria del carisma del líder teñida de acentos maoístas. Y la afinidad entre justicialismo y Revolución, concretizada en diferentes proyectos de poder, da lugar a solidaridades y tensiones que apuntan a dirimir quién es o qué es, en definitiva, el polo de poder en la sociedad política nacional de la época. La antigua tradición populista está atravesada por numerosos conflictos, pero también se extiende en la presencia de lógicas que le eran completamente ajenas o simplemente marginales.

31 La radicalidad que adquirió el peronismo podía ser interpretada (o confundida, para los lectores más puristas) como una versión vernácula de la idea revolucionaria. 0 como concretización nacional de la utopía socialista. Ello dio lugar a diferentes tentativas de síntesis, algunas de ellas comenzaron incluso durante el período del peronismo clásico. 
Desde el punto de vista de la historia intelectual, se produjeron dos grandes intentos de síntesis : tanto desde el lado de los ideólogos marxistas (el peronismo como horizonte de la liberación social y expresión de las luchas obreras) como desde los anhelos antiimperialistas de los nacionalistas (donde el peronismo representaba el vehículo privilegiado de la liberación nacional).

Desde el lado del peronismo, la cultura revolucionaria se insertaba en sus espacios militantes para definir cómo debían establecerse los criterios de la contestación activista. Esto implicó la adopción de un repertorio vasto y diferencial, como el trabajo de agitación, los dispositivos de propaganda, las actividades de vinculación territorial (compromiso en los barrios, alrededor de la población carenciada), de vinculación en los medios obreros (alrededor de los sindicatos), las estrategias de movilización, y, desde ya, los debates sobre la posible creación de partidos armados: ¿insurrección popular o guerra de guerrillas (esta última, en ascenso desde 1959- 1961)? ¿Foco guevarista o guerrilla urbana?

Agreguemos un entramado colectivo que, re-irrumpiendo ${ }^{20}$ en el peronismo, encuentra en éste un espacio ideal para plasmar en su interior un compromiso secular de orígenes mesiánicos: las redes y trayectorias del catolicismo (Donatello L., 2010). La participación de los católicos en diferentes espacios políticos contestatarios constituye una verdadera turbina de politización radical, que puede desembocar, aunque no obligadamente, en la violencia revolucionaria.

El antiliberalismo, asociado a una visión de lo nacional entendido en clave revisionista ${ }^{21}$, representaba un terreno común por demás extendido en tal clima de época. Este antiliberalismo, transformado en radicalidad mesiánica ofrecía un espacio de entente entre las lógicas nacionalistas (dinámica populista) y las ambiciones rupturistas de actores, representaciones y grupos provenientes de horizontes sociales históricamente hostiles al peronismo (dinámica revolucionaria). La relación entre sectores dirigentes (en el sentido vasto, de actores dotados de recursos de poder) y peronismo no era un hecho extraño en la historia de los orígenes de este último, cuando elites anti status quo (Di Tella T., 2011) adhirieron al primer proyecto peronista desde diversos entramados institucionales - Iglesia, Fuerzas Armadas, intelectuales, partidos radicales y conservadores, dirigentes sindicales que se conformaron como entramados de poder. El período que se abre entre 1955 y 1956 verá acrecentar, con el correr de los años, la llegada de estudiantes y activistas que se definirán como peronistas. El control de estas adhesiones por parte de Perón, alejado del poder, devendrá extremadamente parcial, precario. Y estará a la base de la ruptura entre él y Montoneros pocos días antes de su muerte.

Ir al pueblo, reivindicar a la clase trabajadora cuando justamente la socialización y la sociabilidad políticas se encontraban ajenas al universo proletario industrial, significó en Argentina la particularidad de la implantación de una pertenencia colectiva estructurada, la de la adhesión peronista, la de un partido carismático. A diferencia de otras realidades donde se presenta ese mismo tipo de legitimidad (en Europa se trataba de buscar el rostro revolucionario en los explotados del Tercer Mundo; en diferentes países latinoamericanos, la existencia de tradiciones de partidos de izquierda constituía un dato insoslayable), en el caso argentino, el mundo obrero ya presente tenía características sociopolíticas propias - ello obedece más a una estructura política existente que a los condicionamientos socioeconómicos o a los supuestos del enfoque de la modernización. Entonces, hacia 1973, la coexistencia entre populismo peronista y 
partido revolucionario fidelista se traduce estrictamente en una antinomia ${ }^{22}$. Se trata menos de un clivaje que de una tensión: los actores y posicionamientos son cambiantes, las alianzas y discursos provisorios, hasta que, entre las "milicias populares" ${ }^{23}$ y la masacre de Ezeiza (20 de junio de 1973), se cristaliza una oposición aguda: el peronismo en el poder debía erradicar la lucha armada. Es este populismo el que bloquea, en definitiva, la difusión popular de la idea socialista, que en su versión "socialista nacional" no era otra cosa que, en el mejor de los casos, una expresión sinónima de "movimiento peronista". Una parte de la intelectualidad de izquierda y de los partidos armados, munidos de diferentes versiones de guevarismo y de fidelismo, pensaban en la posible influencia de la vía cubana como modelo cuya importación parecía posible. Tal tentativa, en los hechos, representó un fracaso ineluctable.

\section{BIBLIOGRAFÍA}

Aboy Carlés, Gerardo, "Populismo y polarización política”, in Asociación Latinoamericana de Ciencia Política, Noveno Congreso Latinoamericano de Ciencia Política, Montevideo, 26- 28 de julio de 2017.

Altamirano, Carlos, Peronismo y cultura de izquierdas, Buenos Aires, Siglo veintiuno, 2011 (2001).

Álvarez, Yamile, “Aportes para una historia de la Revolución Libertadora en Mendoza”, in Páginas. Escuela de Historia, vol. 8, $\mathrm{n}^{\circ}$ 16, 2016, p. 7-24.

Amaral, Samuel, “Conclusión. Del exilio al poder: la legitimidad recobrada”, in Samuel Amaral y Mariano Ben Plotkin, Perón: del exilio al poder, Buenos Aires, Cántaro, 1993, p. 281-308.

Amaral, Samuel, El movimiento nacional popular. Gino Germani y el peronismo, Sáenz Peña, UNTREF, 2018.

Basquetti, Roberto, Militantes del peronismo revolucionario uno por uno : http:// www.robertobaschetti.com/uno\%20x\%20uno.htm

Bouilly, Felipe, “La Federación Juvenil Comunista como ariete de la ruptura del Partido Comunista de la Argentina, 1967/1969”, Jornadas de Historia Reciente, UNL Santa Fe, 2012.

Cosse, Isabela, Pareja, sexualidad y familia en los años sesenta, Buenos Aires, Siglo Veintiuno, 2010.

Cristiá, Moira, Imaginaire péroniste. Esthétique d'un discours politiques 1966-1976, Rennes, PUR, 2016.

Cucchetti, Humberto, Servir Perón. Trajectoires de la Garde de Fer, Rennes, PUR, 2013.

Cucchetti, Humberto, "Péronisme ou voie cubaine en Argentine : une histoire transnationale par défaut", in Etudes transaméricaines, Institut des Amériques de Rennes, 25 janvier 2019.

Di Tella, Torcuato, Sociología de los procesos políticos. De la movilización social a la organización política, Buenos Aires, El Ateneo, 2011.

Donatello, Luis, Catolicismo y Montoneros. Religión, política y desencanto, Buenos Aires, Manantial, 2010. 
Ehrlich, Laura, "El mito revolucionario de Eva Perón en los años sesenta: política, cultura y mercado editorial", in Carlos Altamirano y Adrián Gorelik, La Argentina como problema. Temas, visiones y pasiones del siglo XX, Buenos Aires, Siglo veintiuno editores, 2018, p. 313-325.

Ehrlich, Laura, "Nacionalismo y arquetipo heroico en la Juventud Peronista a comienzos de la década del '60", in Anuario IEHS, n² 28, 2013, p. 37-57.

Funes, Andres, Una voz en la bruma. El semanario Compañero y la tradición peronista en los años 60, Tesis de Maestría en Ciencia Política, IDAES- Universidad Nacional de General San Martín, 2018.

Georgieff, Guillermina, Nación y Revolución: itinerarios de una controversia en Argentina 1960-1970, Buenos Aires, Prometeo, 2008.

Grabois, Roberto, Memorias de Roberto "Pajarito" Grabois. De Alfredo Palacios a Juan Perón (1955- 1974), Buenos Aires, Corregidor, 2014.

Hilb Claudia y Lutzky Daniel, La Nueva Izquierda argentina 1960-1980. Política y violencia, Buenos Aires, Centro editor de América Latina, 1984.

Hobsbawm, Eric, Historia del siglo XX, Buenos Aires, Crítica, 2010 (1994).

Lanusse, Lucas, Montoneros. El mito de sus 12 fundadores, Buenos Aires, Zeta, 2010 (2007).

Lanusse, Lucas, "Del motor pequeño al grande. El debate acerca de la relación entre lucha política y lucha militar en los orígenes y primeros tiempos de Montoneros", in Cuestiones de Sociología. Revista de Estudios Sociales, $\mathrm{n}^{\circ}$ 3, 2006, p. 117-142.

Levitsky, Steven, La transformación del justicialismo. Del partido sindical al partido clientelista, 19831999, Buenos Aires, Siglo Veintiuno Editora Iberoamericana, 2005.

Manzano, Valeria, La era de la juventud en Argentina. Cultura, política y sexualidad desde Perón hasta Videla, Buenos Aires, Fondo de Cultura económica, 2017.

Neiburg, Federico, Los intelectuales y la invención del peronismo, Buenos Aires, Alianza, 1998.

Ollier, María Matilde, La creencia y la pasión: privado, público y político en la izquierda revolucionaria, Buenos Aires, Ariel, 1998.

Ory, Pascal, Peuple souverain : de la révolution populaire à la radicalité populiste, Paris, Gallimard, 2017.

Rot, Gabriel, Los orígenes perdidos de la guerrilla en la Argentina, Buenos Aires, Waldhuter, 2010 (2000).

Rouquié, Alain, Le siècle de Perón. Essai sur les démocraties hégémoniques, Paris, Seuil, 2016.

Salcedo, Javier, “Estrategias y tácticas de la militancia originaria de Montoneros. 1967- 1969”, in PolHis, año 8, n 16, 2015, p. 224-257.

Slipak, Daniela, Las revistas Montoneras. Cómo la organización construyó su identidad a través de sus publicaciones, Buenos Aires, Siglo veintiuno, 2015.

Sigal, Silvia y Verón, Eliseo, Perón o Muerte. Los fundamentos discursivos del fenómeno peronista, Buenos Aires, Eudeba, 2003 (1988).

Sigal, Silvia, Intelectuales y poder en Argentina, Buenos Aires, Puntosur, 1991.

Spinelli, María Estela, De antiperonistas a peronistas revolucionarios. Las clases medias en el centro de la crisis política argentina (1955- 1973), Buenos Aires, Sudamericana, 2013.

Solanas, Fernando y Gettino, Octavio, La hora de los hornos, Grupo Cine Liberacion, 1968. 
Taguieff, Pierre-André, L'illusion populiste. Essai sur les démagogies de l'âge démocratique, Paris, Champs-Flammarion, 2007 (2002).

Terán, Oscar, Nuestros años sesentas. La formación de la nueva izquierda intelectual argentina, Buenos Aires, Siglo veintiuno, 2017 (1991).

Tortti, María Cristina, El "viejo" partido socialista y los orígenes de la "nueva" izquierda", Prometeo, Buenos Aires, 2009.

Tortti, María Cristina, "Protesta social y "Nueva Izquierda" en la Argentina del "Gran Acuerdo Nacional”, in Hernán Camarero, Pablo Pozzi y Alejandro Schneider, De la Revolución Libertadora al menemismo, Buenos Aires, Imago Mundi, 2000, p. 135-160.

Archives orales de l'auteur.

Publications militantes : Trinchera de la Juventud Peronista, Palabra Argentina, GH, Argentinos a la lucha, 18 de Marzo.

\section{NOTAS}

1. Centrado en la idea de "justicia social", el justicialismo es la expresión utilizada para caracterizar al movimiento peronista. Doctrinariamente, tal caracterización remite a las "20 verdades", principios axiales establecidos por su conductor Juan Domingo Perón en 1950 (segunda mitad de su primera presidencia), y que aluden a la importancia de la representación popular y plebeya, la defensa de los trabajadores (entendidos estos en un sentido laxo, "los que trabajan"), de la soberanía nacional y así como al uso social del capital y de la vida económica. A partir de un rol estatal fuerte, la definición filosófica e incluso geopolítica del peronismo pasa por una oposición tajante al "capitalismo liberal" y al "colectivismo marxista", sosteniendo así el principio de la Tercera posición (troisième voie).

2. Oficial del ejército y miembro del grupo de militares que pergeñó el golpe de Estado de 1943, Perón comienza una carrera administrativa ascendiente al frente de la Secretaría de Trabajo y Previsión, donde realiza importantes transformaciones sociales e interactúa con los sindicatos argentinos. Tales medidas lo erigen en ícono de la clase obrera, vínculo a menudo conflictivo sobre el cual se funda el movimiento peronista. Después de un largo exilio (1955- 1973), es elegido nuevamente presidente en 1973, pocos meses antes de morir al año siguiente.

3. Segunda esposa de Perón, "Evita" es asociada a toda una vasta obra de acción social realizada desde el Estado peronista y destinada a sectores desfavorecidos. Sus vínculos con el sindicalismo argentino fueron por demás ceñidos. Sus discursos enfatizaban la radicalidad de la "revolución justicialista", y están asociados a un fuerte resentimiento político, plebeyo y vindicativo. Falleció en 1952, afectada por un tumor cancerígeno.

4. Como es de suponer, citamos sólo algunas lecturas significativas, entre otras que habrían podido señalarse.

5. Lo que no quiere decir que el peronismo haya sido un destino omnipresente en la politización juvenil.

6. En relación a la cuestión de la legitimidad, ver Samuel Amaral (1993), y Claudia Hilb- Daniel Lutzky (1984).

7. Núcleos activistas de oposición a las autoridades militares y civiles de turno que emergen con claridad durante 1956, ante los proyectos de "desperonización" llevados adelante por la Revolución Libertadora, nombre otorgado a la revuelta cívico-militar que produjo la caída de Perón. 
8. Ver, en este sentido, el caso de las escisiones en el interior del Partido Socialista Argentino (Tortti MC., 2009) o la fundación del Partido Comunista Argentino en 1969 (Bouilly F., 2012).

9. La organización Montoneros representó la principal guerrilla argentina, implantada en particular en los medios urbanos. Sus grupos fundadores se fueron formando en la segunda mitad de los años 1960, recibiendo algunos de sus dirigentes instrucción militar en Cuba. Con el secuestro y asesinato del ex presidente Pedro Aramburu el primero de junio de 1970, eminente figura del antiperonismo que derrocó a Perón en 1955, la organización expresó su voluntad vanguardista dentro del peronismo y su objetivo de erradicar toda "traición interna". Opuesta a la "burocracia sindical", en 1973 era inocultable que su antagonismo principal se encarnaba en el liderazgo del propio líder justicialista.

10. Tal es el caso, por ejemplo, de la publicación El Guerrillero, del Comando Nacional de la Resistencia Peronista, uno de los más insurreccionales de la época.

11. Ver, por ejemplo, la guerrilla peronista implantada entre Tucumán y Santiago del Estero "Uturuncos".

12. En el contexto de inicios de los años 1970 , surgieron publicaciones estrictamente vinculadas a Montoneros (Slipak D., 2015).

13. Ver, por ejemplo : Cucchetti H., 2013.

14. Aunque conviene reconocer que la idea de populismo está mucho más presente en el lenguaje de los autores que en el de los actores, quienes muchas veces adoptan tal identidad como consecuencia de la proliferación de discursos exógenos.

15. Nuestro archivo oral, iniciado en 2005, sigue engrosándose au fur et à mesure. Cuenta con más de 30 entrevistas biográficas que buscan erigirse en verdaderos relatos de vida.

16. Declaración de Roberto Grabois en el documental La hora de los hornos (1968).

17. En sus memorias, el mismo actor sostiene que Cuba siguió sosteniendo el apoyo al "aparato" guerrillero en Argentina durante el gobierno peronista, a pesar de las relaciones económicas sostenidas por el ministro de economía peronista José Gelbard y la isla, tendiente a evitar su bloqueo económico (Grabois R., 2014 : 462- 463).

18. “Por qué somos peronistas de base ?” de 1971 (comillas en el texto).

19. Ibíd. (comillas en el texto).

20. Ya que el pasaje del catolicismo al peronismo, y las síntesis entre ambos fenómenos, son bien extendidas durante el período 1945- 1955. Conviene señalar que la caída de Perón en septiembre de 1955 es el desenlace de un agudo conflicto entre el entonces presidente y la Iglesia: en noviembre de 1954, Perón denuncia la infiltración clerical en política, desatando un conjunto de medidas de gobierno para golpear fuertemente el rol público y social de las instituciones eclesiásticas. Las movilizaciones católicas opositoras durante 1955 permiten coagular todo un vasto universo antiperonista, el que es sostenido militarmente por importantes fracciones de las Fuerzas armadas.

21. Corriente historiográfica que propone establecer continuidades entre figuras y procesos del siglo XIX y siglo XX.

22. En este sentido, la tensión Perón o muerte analizada por Silvia Sigal y Eliseo Verón (2003), entre proyecto totalitario de Montoneros de un lado, y distancia entre peronismo y totalitarismo, de otro, (en otros términos, el Perón de los revolucionarios armados, y el populismo desestabilizador, paradójicamente democrático e institucional -aunque poco republicano- del primer peronismo) se manifestaron, al menos en los episodios de 1973 y 1974 en términos irreductibles. Tensión y no clivaje que incluso penetró diferentes experiencias militantes y proyectos intelectuales. Gerardo Aboy Carlés sostiene que, por ejemplo, los significados del populismo en Ernesto Laclau (joven militante en los años 1960) son diversos, teorizando aspectos centrales del populismo clásico, pero dando lugar a interpretaciones claramente jacobinas, cristalizadas sobre todo en su célebre último libro La Razón populista (Aboy Carlés G., 2017). Esto permite explicar, desde nuestro punto de vista, la influencia del intelectual argentino en las filas 
de experiencias de izquierda europea como Podemos y la France Insoumise. Podemos remitir, igualmente, a una contribución reciente de Cucchetti H. (2019).

23. Rodolfo Galimberti, dirigente Montonero de la Juventud Peronista, propuso, en abril de 1973, la creación de "milicias populares", generando un profundo malestar en Perón y su entorno.

\section{RESÚMENES}

Un conjunto de debates sigue girando alrededor del fenómeno de politización y radicalización militante que se inicia durante la década de 1960. Las categorías de Nueva Izquierda, Izquierda Revolucionaria, Peronismo Revolucionario son utilizadas para dar cuenta de tal proceso de agitación estudiantil y de creación de entramados organizativos con vocación revolucionaria de toma del poder de Estado. El abanico de actores, de redes y de métodos de acción contestataria es, sin embargo, más amplio. Este involucra un espacio abigarrado y a veces heteróclito de referencias y de pertenencias militantes. El peronismo mismo es transformado por tales circunstancias históricas y por el advenimiento de una radicalidad política que parece trastocar los fundamentos de la autoridad discursiva (Perón, el orden sindical, cierto estatus partidario legítimo). Retomando algunos trabajos sobre el tema en cuestión, la presente propuesta se propone ir al fondo de una discusión en la que los procesos aludidos son abordados a partir de la pertinencia o no de la categoría de populismo. ¿Es el populismo una categoría pertinente para dar cuenta del período en cuestión? ¿Es posible pensar en términos de "militancia populista" o se trata, por el contrario, de una ruptura en los acontecimientos que pone en tela de juicio la continuidad de una versión clásica del fenómeno peronista? Entre lectura bibliográfica y análisis de manifestaciones empíricas, este texto pretende fijar las bases conceptuales y metodológicas de tal tipo de interrogación.

Concernant le phénomène de la politisation et de la radicalisation militante qui débute au cours des années 1960, nombre de débats demeurent toujours d'actualité. Les catégories de Nouvelle Gauche, de Gauche révolutionnaire ou encore de Péronisme révolutionnaire sont mises en œuvre pour rendre compte des mouvements des étudiants et de l'instauration de tissus organisationnels à vocation révolutionnaire pour conquérir le pouvoir. L'éventail d'acteurs, de réseaux et de méthodes d'actions contestataires restent pourtant extrêmement large. Cet horizon-là implique un espace souvent hétéroclite de références et de compétences militantes. Le péronisme luimême est secoué et transformé par ces mêmes circonstances historiques, notamment par l'essor d'une radicalité politique qui semble bouleverser l'autorité discursive et politique, à savoir, Perón, les syndicats et le parti. En faisant appel à certains travaux qui traitent de la question, notre contribution se propose d'aller au cœur d'un débat où les processus mentionnés sont abordés à partir de la pertinence, ou du manque de pertinence, de l'idée de populisme. Le populisme est-il une catégorie appropriée pour aborder la période de la radicalisation? Est-il possible de penser en termes de «militantisme populiste »? Ou bien, s'agit-il d'une rupture dans les événements qui met en cause la continuité du péronisme classique? Entre analyse bibliographique et analyse de manifestations empiriques, notre travail s'efforce d'orienter les bases conceptuelles et méthodologiques de l'interrogation proposée.

A series of debates continue to revolve around the phenomenon of politicization and militant radicalization that began during the 1960s. The categories of New Left, Revolutionary Left, and 
Revolutionary Peronism are used to account for such a process of student agitation and the creation of organizational frameworks with a revolutionary vocation to seize state power. The range of actors, networks and methods of contestation is nevertheless broader. This involves a variegated and sometimes heteroclite space of references and militant belongings. Peronism itself is transformed by such historical circumstances and by the advent of a political radicalism that seems to disrupt the foundations of discursive authority (Perón, the union order, a certain legitimate party status). Returning to some work on the subject in question, this proposal aims to go to the bottom of a discussion in which the processes referred to are addressed from the relevance or not of the category of populism. Is populism a relevant category to account for the period in question? Is it possible to think in terms of "populist militancy" or is it, on the contrary, a break in the events that calls into question the continuity of a classic version of the Peronist phenomenon? Between bibliographical reading and analysis of empirical manifestations, this text intends to establish the conceptual and methodological bases of such type of interrogation.

\section{ÍNDICE}

Palabras claves: peronismo, populismo, lucha armada, activismo, militancia revolucionaria Mots-clés: péronisme, populisme, lutte armée, activisme, militantisme révolutionnaire Keywords: peronism, populism, armed struggle, activism, revolutionary militancy

\section{AUTOR}

\section{HUMBERTO CUCCHETTI}

Investigador en el Consejo Nacional de Investigaciones Científicas y Técnicas (CONICET Argentina), Habilitado para dirigir investigaciones (HDR Sorbonne Université), autor de diversos libros (por ejemplo, “Servir Perón”, PUR, 2013), de artículos en revistas con referato, el autor realiza proyectos de investigación en perspectiva transnacional y comparativa sobre trayectorias militantes, reconversiones y élites político-estatales América latina - Europa. 